Article

\title{
Rural Entrepreneurship Strategies: Empirical Experience in the Northern Sub-Plateau of Spain
}

\author{
Miriam López *(1), Adolfo Cazorla $₫$ and Milagros del Pilar Panta $(1$ \\ Gesplan Research Group, Universidad Politécnica de Madrid, 7, 28040 Madrid, Spain; \\ adolfo.cazorla@upm.es (A.C.); milagros.panta.monteza@alumnos.upm.es (M.P.P.) \\ * Correspondence: miriam.lopez@upm.es; Tel.: +34-91-067-0980
}

Received: 31 December 2018; Accepted: 21 February 2019; Published: 26 February 2019

check for updates

\begin{abstract}
Entrepreneurship initiatives that could have an impact in rural areas are embedded in broader agricultural, rural development or structural policies at the European Union level. Nevertheless, there is a prevailing lack of rural strategies focused on entrepreneurship, especially in aging and depopulated EU rural regions. In this context, the need to have real experiences as an empirical contribution to the academic, political and professional spheres is identified. The purpose of this paper is to contribute to the current empirical research throughout a real experience and its capitalization. The paper portrays the design and implementation of a rural entrepreneurship strategy, in a very depopulated area, engaging civil society participation by adapting the 'Working With People' model to the idiosyncratic conditions of the context. The study then considers the main factors of this strategy by analyzing its application in a wider area in the province of Ávila, Spain. We find that rural entrepreneurship can be enriched by strategies designed and assessed by the beneficiaries from the early stages of formulation. This experience is supported by the 'Fundación Tatiana Pérez de Guzmán el Bueno', a non-profit institution that manages its legacy to achieve social goals in youth training, scientific research and environmental fields.
\end{abstract}

Keywords: rural entrepreneurship; rural development; experience capitalization; Working With People; capacity building; public-private partnership

\section{Introduction}

Entrepreneurship is an old but continually emerging field that attracts the attention of academics, policymakers and practitioners in various fields of economics, finance, management and sociology [1]. In recent decades, it has been studied as a catalyst for development and as a key factor in achieving economic growth, job creation and increased productivity [2,3]. It is also seen as a process in which an individual creates innovation opportunities that lead to additional and innovative contributions to society [4-7]. Nowadays, the theory of entrepreneurship has expanded to new concepts where entrepreneurship is not only considered for its economic potential but also for subjective welfare and non-economic wellbeing [8], which people can achieve through their capabilities [9].

All these characteristics that define entrepreneurship are studied, taking into account their relationship with the context in which they occur. Research shows that geographical locations, socio-economic, institutional and cultural factors play a crucial role in the entrepreneurial activity [10-16] and can offer both opportunities and barriers for business behavior [11]. Thus, many scholars today agree that entrepreneurship is the result of the interaction between individual attributes and the local surrounding environment [17-19] and, therefore, it is not addressed as an isolated economic activity but as a social activity embedded in many cultural and economic contexts [20]. In this sense, several studies relate entrepreneurship with spatial context and more recently with the concept of places. Spatial contexts is seen as a physical extension that entails 
proximity or distance in social relations while the notion of places entails that spatial context embraces experiential dimensions such as representations, meanings, imagery and emotional attachment to locations that can affect entrepreneurship in several ways [21].

In the case of rural areas, entrepreneurship presents attributes derived from the context in which it is developed and from the generalized association between this environment and the resources on which rural business rely [22-24]. Examples of these attributes include large distances from points of sale, specialized market, predominance of primary sector activities and dense "networks" of mutual control, etc., which determine entrepreneurial activities [25]. Furthermore, additional issues of declining economic activity, emigration of the labor force and the shortage of young entrepreneurs are more significant in depopulated rural areas, which makes it more difficult to carry our business activities and has negative impacts on the attractiveness of the region as a place to live and work [26].

Rural entrepreneurship is a European concern, most notably in the UK and Spain [27], although empirical research in this field is relatively sparse [28]. At the European Union (EU) level, predominantly rural regions (where the rural population is more than $50 \%$ ) [29] represent $44 \%$ of the total area and $19 \%$ of the population [30]. These areas differ in their population densities, distance to urban centers, labor markets and the levels of co-operation between different rural actors and organizations between Member States and also between the different regions within Member States.

The initiatives that support rural entrepreneurship at an EU level are mainly promoted within the public sphere and are integrated in broader strategies such as regional, cohesion or agricultural policies, and in line with the goals set by the Europe 2020 strategy. In this framework, entrepreneurship is a key factor of diversification that has become increasingly important whilst the share of activities related to the primary sector has declined [31]. Among the initiatives that can support rural entrepreneurship, there is support for young entrepreneurs in the early stages of creating their businesses, as part of the measures of national or regional rural development programs financed with EAFRD funds (European Agricultural Fund for Rural Development). Support from structural funds is also available for different purposes such as vocational training or education. [32].

Another initiative that stands out for its original focus, and which has been an inspiration for this study, is the LEADER (acronym in French-Liaison entre action de développement de l'économie rurale-meaning Links between actions for the development of the rural economy) [33]. LEADER began in the early 1990s as a Community initiative and was then integrated into the regional and national rural development programs of the common agricultural policy and its second pillar. This initiative represents an innovative type of action that highlights the importance of endogenous development and entrepreneurship to mobilize the economic potential of rural territories and which implies a bottom-up process and social mobilization [34-36]. Local Action Groups (LAGs) were created to operate these programs and since then they have assumed the role of managing and promoting activities in their respective areas of action with the specific purpose of developing local capacity in terms of skills and competencies [37]. In this type of action, there has been an orientation towards the diversification of activities that, together with the presence of small agricultural enterprises and established collaborative ties, have represented a valuable human capital that must be supported in its evolution and permanence [38]. Through this configuration, development strategies have proven to be more effective and efficient in many areas [34]. However, despite the achievements of this model, the problems of depopulation, aging, inequality and the lack of opportunities remain [36].

Considering the above, our study is focused on planning strategies to foster rural entrepreneurship based on participatory processes and covers the period between 2014-2018. The main research question that we will address in this paper is:

Are participatory processes relevant in the early stages of planning to the success of rural entrepreneurship strategies? Can these participatory processes compensate to some extent the lack of public initiative and funds in rural entrepreneurship? 
In this paper, we understand that "something (A) is relevant to a task (T) if it increases the likelihood of accomplishing the goal (G), which is implied by $\mathrm{T}^{\prime \prime}$ [39]. Thus, the participatory process is relevant to the rural entrepreneurship strategy if it increases the likelihood of achieving the implicit objective in the rural entrepreneurship strategy. Likewise, we adopt "satisfaction of the parties involved" as a definition of success following the standards of the International Project Management Association, IPMA [40].

We find that rural entrepreneurship can be enriched by strategies that are designed and assessed taking participatory processes into account from the early stages of formulation. In some of these strategies, participatory processes can compensate for the absence of initiatives promoted from the public sphere.

In addition, this paper aims to contribute to the current empirical research throughout a planning experience and its subsequent documentation as a case study. In this case study, the documentation process shows some relevant aspects of good practices documentation according to the Food and Agriculture Organization of the United Nations (FAO) [41]. This experience along with a scaling-up process in rural areas of central Spain let obtain a number of lessons from the experience.

The heterogeneity of rural areas requires the development of strategies or action models that can be adapted to different environments and configured to appropriate entrepreneurial ecosystems [42,43].

\section{Empirical Basis: Case Studies}

The empirical basis of this paper includes two case studies promoted by a private Spanish Foundation (Fundación Tatiana Pérez de Guzmán el Bueno, hereinafter referred to as FTPGB) in line with its research and training goals. These case studies represent two pathways to stimulate entrepreneurship. The main aspects that make them significant to this research are:

- Aging and depopulated zones included in the area of action: the two case studies include areas with relevant characteristics for the scope of the investigation.

- Planning based on participatory processes.

- Data identification and collection is available and accessible.

- Meaningfulness of available information: the available information can help to answer the key research questions.

- Maturity: the case studies are developed enough to provide relevant insights.

- Learning: some parts of insights can be expressed in generalizable terms.

- Scaling-up: a case study can be scaled-up throughout the other case study.

- Flexibility: the case studies allow the research group to take part in running the programs and collecting data for research at the same time, with a high degree of flexibility and independence.

\subsection{Case Studies Overview}

The case studies are located in the province of Ávila (NUTS3-Nomenclature of Territorial Units for Statistics Level 3-administrative region) [44], in central Spain. Within this classification, and according to the definition of urban-rural typologies, the province of Ávila is considered a 'predominantly rural' area. As a territorial unit, it is included in a higher unit called the Autonomous Community of Castilla y León (NUTS2) which is considered a 'developed region' as it has a GDP per capita above $90 \%$ of the European average. This Autonomous Community is a region located in the northern plateau. In addition, $98.1 \%$ of its area is more than 600 meters above sea level and $31.6 \%$ is more than 1,000 meters above sea level. These conditions determine a continental-type climate with high temperature contrasts and scarce rainfall in the summer, and with significant spatial and seasonal inequalities [45]. The population density is 25.7 inhabitants per $\mathrm{km}^{2}$ in the NUTS2 and 19.9 inhabitants per $\mathrm{km}^{2}$ in the province of Ávila-NUTS3 - far from the national average, which is 92.05 inhabitants per $\mathrm{km}^{2}$ [46] or the European Union-UE28-average, which is 117.5 inhabitants per $\mathrm{km}^{2}$ [47]. 
Considering the above, Case study 1 comprises 17 municipalities (Figure 1 ) of the Sierra de Ávila and it is configured as a pilot project. The territorial context stands out for being one of the most sparsely populated areas of the Spanish territory, with 1632 inhabitants in $379 \mathrm{~km}^{2}$, representing a population density of 4.77 inhabitants per $\mathrm{km}^{2}$. The low population density stands out compared to rural Spain, which has an average of 19.79 inhabitants / $\mathrm{km}^{2}$ [48].

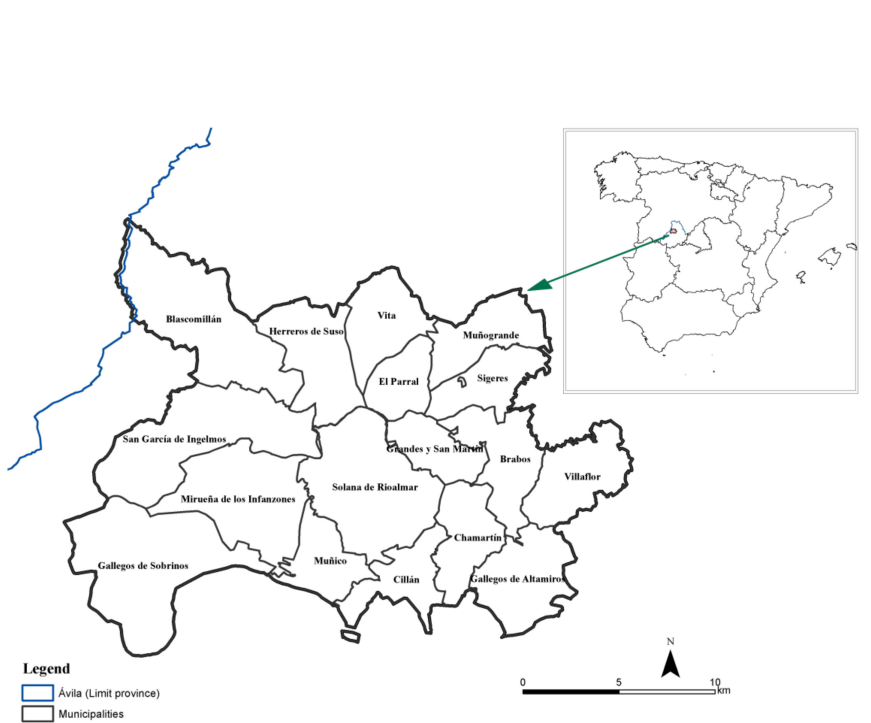

(a)

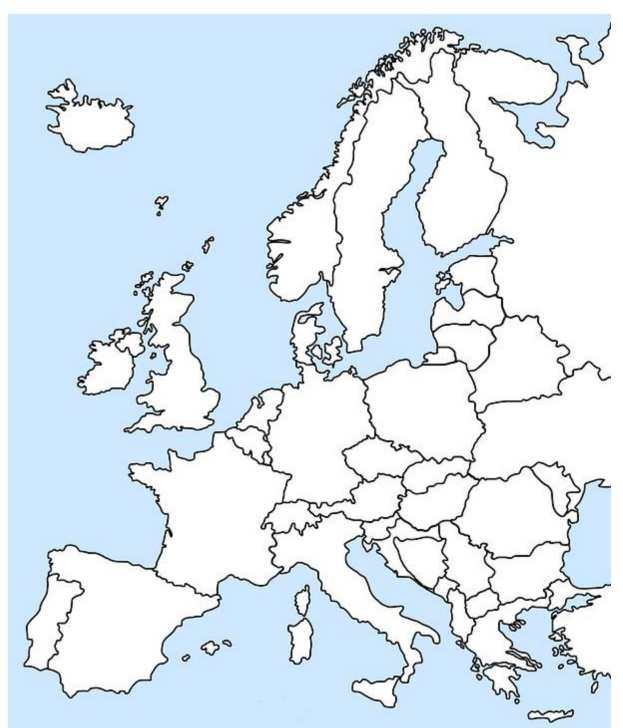

(b)

Figure 1. Location map: (a) national and regional scale; (b) European scale.

Despite the small population and an aging population pyramid, the area has a cohesive geographic unit with numerous natural, cultural and environmental resources. The predominant productive activity is dry farming, with $40.5 \%$ of the area occupied by meadows and pastures (mainly barley and wheat) and livestock production is focused on bovine meat and milk [49]. The area is well connected with a series of road infrastructures that facilitate access to the nearest capitals, Avila and Salamanca, and even to large urban centres like Madrid. It is therefore an area with a great potential in terms of searching for new entrepreneurial opportunities and creating synergies between different local actors. The entrepreneurship sought must be able to generate balanced economic and social development, with a strong innovative character capable of generating new business models, new products and new production techniques [50].

For more than 15 years, in the rural areas of Sierra de Avila, various development programs based on the European LEADER approach have been carried out through national PRODER programs (acronym in Spanish-Programa Operativo de Desarrollo y Diversificación Económica de Zonas Rurales-meaning operational programme for the development and economic diversification of rural areas) which are a set of programs for rural development that implement endogenous development measures designed and applied at a national level [51]. In general, these programs were implemented in rural regions not covered by the LEADER initiative and, since the LEADER extended its application to all these rural areas from the programming period 2007-2013, PRODER programs were gradually no longer applied. However, the program's territory is one of the areas with less activity compared to other more populated and dynamic rural surroundings. LEADER and PRODER Programmes have tended to penalise disadvantaged rural zones that are facing problems of depopulation and social and economic decline [52]. During the last few years, only small rural tourism initiatives or services aimed at improving internet access have been launched. At a provincial level, initiatives have been implemented to facilitate consistent financial support to small entrepreneurs, but they have not been effective due to the small number of financial aid applicants. Apart from these initiatives, activities 
related to the promotion of local products supported by the local action group, municipal associations, and other agents have been carried out.

The pilot project consists of the planning and implementation of an entrepreneurship program called "Young entrepreneurs for the sustainability of rural areas" (JESTeR Program). In this program, the FTPGB acts as the promoter and sponsor, and Gesplan (a research group from the 'Universidad Politécnica de Madrid, Spain') is responsible for its planning and execution.

The JESTeR program is configured as a new application of the Working with People (WWP) approach in a specific context and conditions. The objective pursued with the implementation of this program is to identify potential entrepreneurship resources, to promote entrepreneurship projects with a sustainable and environmentally friendly approach, and to facilitate conditions to enhance synergies between different actors in several rural municipalities which are characterized by depopulation and aging. It is aimed at the local population, giving special priority to women and young people. The elements that characterize the program are the result of participatory collaboration between the different stakeholders involved. The identification of stakeholders, local action groups, public and private associations, etc., based in the territory, helps to gather information on resources, potential and other actions carried out by rural development initiatives. Within this collaboration framework, it has been possible to generate an entrepreneurship strategy, in which the participation of local people has played a key role.

After continuous work, it has been possible to incorporate several tools into the pilot project to promote entrepreneurship. Table 1 shows tools that are designed to configure this strategy, management model and entrepreneurship initiatives launched.

Table 1. Configuration and results (JESTeR Program).

\begin{tabular}{|c|c|c|}
\hline Tools & Management Model & Ventures \\
\hline 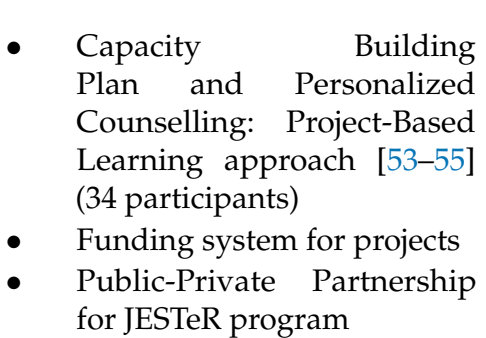 & See Figure 2 & $\begin{array}{c}2 \text { calls for Projects } \\
53 \text { Preliminary Project ideas } \\
22 \text { Defined Project ideas } \\
6 \text { Projects launched and funded } \\
11 \text { promoters involved }\end{array}$ \\
\hline
\end{tabular}

The six projects that have been launched are distributed within the thematic areas of the strategy as shown in Table 2:

Table 2. Projects and thematic areas.

\begin{tabular}{c} 
Thematic Axis 1: Livestock Farming and Agri-Food \\
$\begin{array}{c}\text { Poultry project: Egg production (Free-ranging hens) }{ }^{1} \\
\text { Beekeeping project 1: Honey production (mixed flower and oak) }{ }^{1} \\
\text { Beekeeping project 2: Honey production (mixed flower and oak) }{ }^{2} \\
\text { Cattle project: Beef cattle feedlot }{ }^{2}\end{array}$ \\
\hline Thematic Axis 2: Tourism, Cultural Heritage and Crafts \\
\hline none \\
\hline Thematic Axis 3: Non-Agri-Food and Livestock SMEs \\
\hline Mechanical project: Innovation in agricultural plowing ${ }^{1}$ \\
ICT services Project: Online sale (Parapharmacy, dietetics and cosmetic products) ${ }^{1}$ \\
${ }^{1}$ First call for projects. ${ }^{2}$ Second call for projects.
\end{tabular}




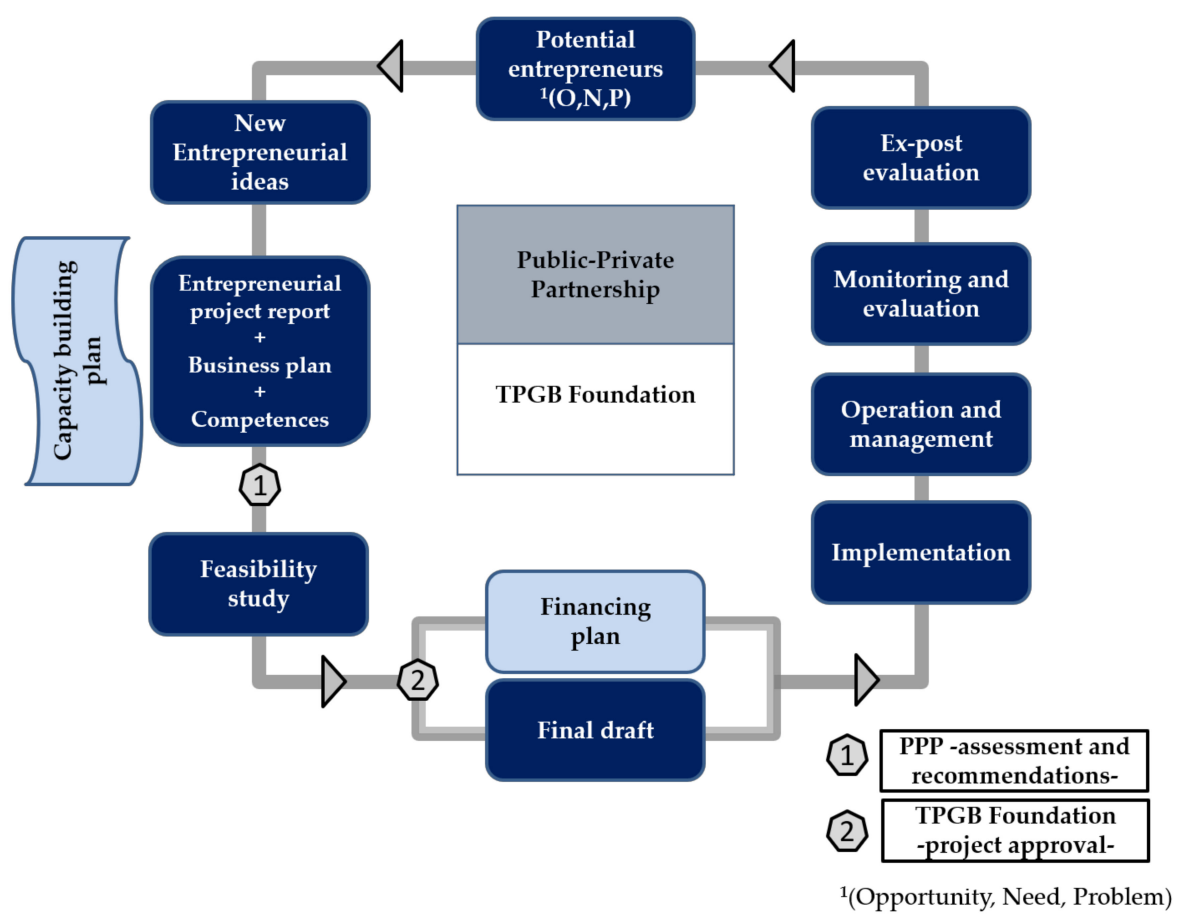

Figure 2. Entrepreneur project management cycle. Source: Adapted and modified from the project cycle by Trueba et al [56].

The strategy has been implemented through a continuous process of calls for rural entrepreneurs. The process has been organized following the management model implementation shown in Figure 2. The 'entrepreneur project management model' integrates different processes designed and agreed between the local population and the actors in the public and private sector. It is a model that follows the project cycle [56], incorporating expert knowledge and experienced knowledge between the planning team and the affected population in each of the different phases [57]. It is a flexible management model, which allows adjustments to be made as new information is obtained and which also leads to the implementation of new projects in the territory.

According to this management model, the process starts with the identification of 'potential entrepreneurs' through an open call for those who desire to launch or to improve an entrepreneurial initiative from an innovative point of view. In this stage, the first preliminary 'project ideas' are shared through meetings and informative workshops, and participants provide a brief report including information on their project ideas and training needs. Under the framework of the 'capacity building plan', those entrepreneurs interested in continuing in the program are supported by technical advisors along the process to generate their own Entrepreneurial Project Proposal and associated Business Plan. Subsequently, a Public Private Partnership (PPP) [58] assesses each of the proposals presented by the entrepreneurs based on socio-economic, technical and environmental indicators as well as the entrepreneur's project management skills demonstrated throughout personal interviews.

The result is a project appraisal report with recommendations for improvement that are shared with the entrepreneurs so they can be shared and included in the project. After this process, the PPP's planning team performs a 'feasibility study' of the project, which then moves to the FTPGB for approval. For each of the projects approved by the Foundation, a 'Financing Plan' is established according to the specificities of each project and the conditions are agreed by the parties involved. Once the project is launched by the entrepreneur and the investments are verified, the project is then passed to the 'operation and management' stage. 'Monitoring and evaluation' activities to check the project's actions and resource management are conducted and documented every six months and an 'ex-post evaluation' is also planned three years after the implementation. 
Case study 2 is related to the program called 'Emprende 1.131 Program', which is an entrepreneurship strategy that was born in 2016 and has also been promoted by the FTPGB in order to develop the entrepreneurial potential of the province of Ávila. Although the province has heterogeneous municipalities in terms of population density, it is an area that includes numerous depopulated rural municipalities as characterized in the pilot experience and with a great significance of the rural areas in the whole territorial context.

This case study is based on the main factors of the pilot project (Case study 1) and shares key structural and contextual elements of the pilot strategy, but with a wider territorial, population and resource implication. Thus, scaling-up has been addressed, allowing lessons to be learned from the experience in a broader context. Table 3 shows the tools used in the strategy, management model and entrepreneurship initiatives that were launched. The management model has had the collaboration of entities in the academic field, including the University of Salamanca, and some regional government institutions such as the city council of Ávila.

Table 3. Configuration and results ('Emprende 1.131' Program).

\begin{tabular}{llcc}
\hline \multicolumn{2}{c}{ Tools } & Management Model & Ventures \\
\hline - Training and mentoring & & \\
programs (83 participants, & & 2 calls for Projects \\
14 trainers, 37 mentors and & See Figure 2 (note that & 104 Preliminary Project ideas \\
1 coach) & management model has been & 48 Defined Project ideas \\
- Funding system & adapted to new tools and there are & 30 Projects launched \\
- $\quad$ Evaluation committee & new coworking spaces available) & (48 people involved) \\
- Coworking space & & 14 Funded Projects \\
- Networking platform & & (26 people involved) \\
\hline
\end{tabular}

The 48 project ideas that have been part of the annual calls have been distributed in three thematic areas:

- General thematic area (34 projects),

- Social thematic area (4 projects),

- Agri-food thematic area (10 projects).

It is important to highlight that the three thematic areas were definitively defined in the second call, leaving a general area open to any topic in the first call. This may be the reason why the agri-food area or social area have had greater participation once specific programs have been defined.

The call for applications for the year 2019 (3rd call) has recently been launched, but the information is not yet available, so it is not part of this study.

\section{Methodology}

The methodology, essentially qualitative, has been adapted to the needs of all phases shown in Figure 3 and described below. Data collection took place between April 2014 and June 2018. 

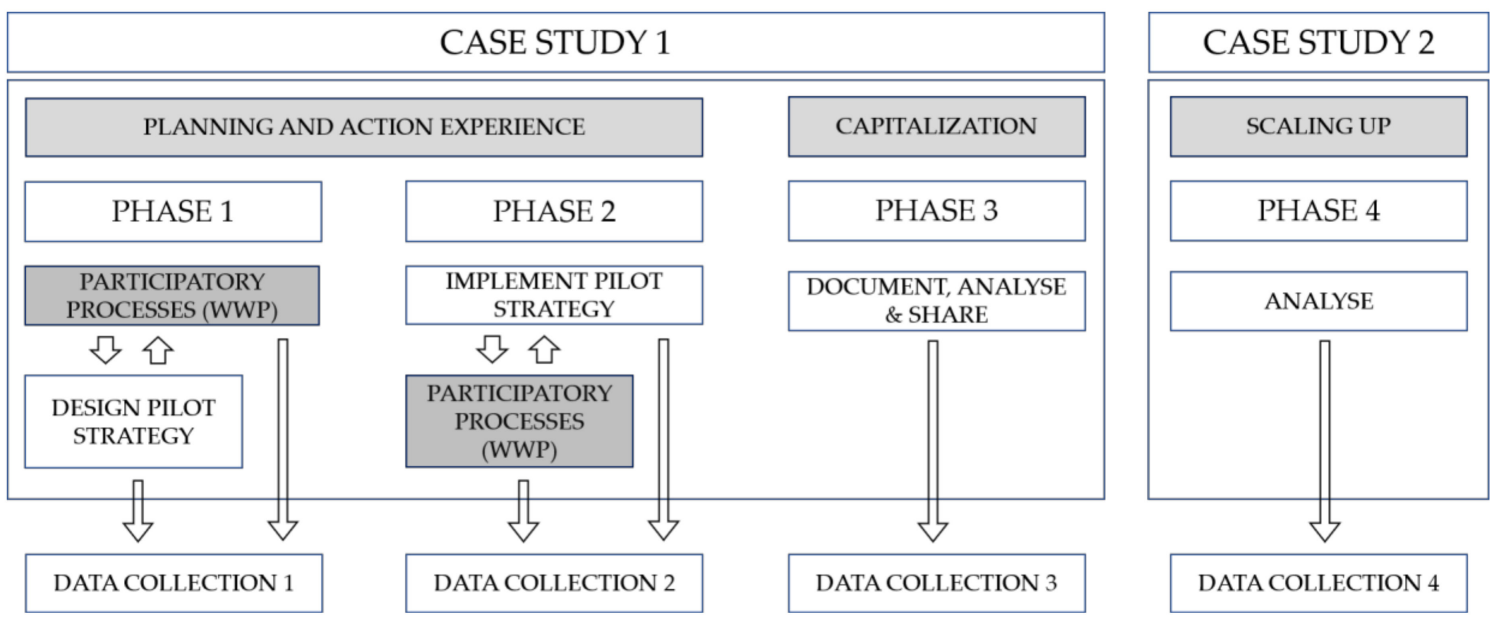

Figure 3. Methodological scheme.

\subsection{Data Collection}

Data collection 1: Data collection in phase one comes from both participatory processes and the examination of the pilot strategy's design. The approach for the participatory process was focused primarily on young people and women but with an open approach to other sectors of the population given the low population density, masculinization and aging of the territory. As a starting point, 23 semi-structured interviews were conducted, involving 17 representatives of the municipal governments, three representatives of the provincial government and three representatives of municipal associations. This has been followed by workshops and roundtables aimed at the local population: four workshops were carried out in which 113 local people interested in the program participated, of which, $72 \%$ were under 40 and $45 \%$ were women. Similarly, three workshops with entrepreneurs took place. On this occasion, 56 people participated, 76\% were men aged over 40 . Subsequently, roundtables were carried out with the participation of 39 entrepreneurs with ideas for new ventures. Throughout these activities, the elements that should contain the strategy to promote and encourage territorial entrepreneurship started to be defined. The examination of pilot strategy design and its reappraisal from local participatory processes has also served to identify key elements of the planning process.

Data collection 2: In the second phase, data collection comes from both the examination of implementation results and the participatory process. Three groups of actors can be distinguished in the participatory process of this phase. The first group is the PPP of the pilot strategy, whose role is to assess entrepreneurship projects presented throughout every call. This group is made up of six municipal representatives, four serial entrepreneurs, three rural facilitators and four representatives of the academic field. Within this group, data collection has been carried out through meetings in which new criteria, possible modifications and application guidelines have been identified. A second group consists of the entrepreneurs involved in the program who were interviewed over several periods throughout the venture's implementation. A third group consists of the representatives of the municipal governments, who have participated through regular meetings.

Data collection 3: In the third phase, data collection comes from examining the process of experience capitalization. According to the FAO definition [41], "Experience capitalization is an iterative process through which an experience (with its successes and failures) is identified, valued, documented and shared. This systematic approach allows the learning of lessons and the identification of innovations and good practices. Thanks to this approach, a practice can be adapted and improved and may thereafter be adopted by others, be implemented on a larger scale and increase its impact". Capitalizing an experience therefore allows knowledge to be generated, which can then be shared and used to promote. A first stage in the capitalization process is the preparation in which the experience, 
people involved, and activities are identified. The second stage integrates the collection, organization and analysis of information, documentation and dissemination of the results.

Data collection 4: Phase 4 refers to case study 2 which is the scaling up process. Scaling up usually involves replication of successful pilot interventions in order to benefit more people and create lasting change [59]. The data in this phase has been collected from examining activities carried out and reports provided by head promoters and managers of the 'Emprende 1.131' program.

\subsection{Working with People (WWP) Approach}

Given the importance of WWP to the participatory process of this study, this sub-section will develop this approach from a theoretical and practical point of view.

The empirical experience that has taken place is based on the basis of planning as social learning $[60,61]$ and, especially, on the derived methodological approach of WWP [62-64]. The implementation of this approach has resulted in different applications that have adapted the components to different contexts and regions, with their specific conditions. Among the predecessors to our case study, the following application cases are highlighted: in the North Highland of the Community of Madrid in Spain, related to a Public Private Partnership focus on promoting entrepreneurship [58]; in Aymara's communities of Puno, Peru, related to an entrepreneurship focus on craftswomen [64,65]; in the Region of Murcia, Spain, related to organic agricultural and biodynamic crops [66]; in the Region of La Macarena, Colombia, related to strategies for the eradication of illicit crops [67]; in the Region of Cuenca, Spain, related to a hydraulic engineering project [68]; and in Rural Regions of Romania, related to project management competencies affecting regional development [69].

The WWP model is configured as a meta-model whose application results in a professional practice that connects knowledge and actions, to develop, implement and evaluate development projects in rural areas. The guiding principles of this model are: respect and primacy for the people, to guarantee social well-being and sustainable development, a bottom-up and multidisciplinary approach and an endogenous and integrated approach.

The model highlights the importance of the local participation processes, skills acquisition and agents' mobilization to ensure that entrepreneurs have the appropriate skills to manage their projects and achieve public-private interaction. In addition, the WWP model seeks to implement projects, and not activities, taking into account the traditions and values, respecting people and caring for the environment. These values should be included in the projects to achieve long-term success. Innovation in the search for new solutions, the bottom-up approach and the incorporation of the territorial approach enables the articulation and design of an effective strategy to promote development aimed at solving the real problems faced by the population [63].

Given the WWP principles mentioned above, the model incorporates three pillars or basic components: social-ethical, technical-entrepreneurial and political-contextual. According to this meta-model, in order to manage the relationship of these three components, it is necessary to include the planning entrepreneur role, which is an intermediary between the public and private powers, who also acts as a resource manager capable of negotiating in turbulent environments with various actors in order to connect public efforts with social demands. Within the pilot strategy framework, the planning entrepreneur role has been assumed by a university research group, to which the authors of this article belong. This role has been integrated within the pilot strategy framework as part of the Public Private Partnership of the strategy management model. The structure of the WWP model in three pillars organizes the participatory processes and the data collection to infer the results in the pilot strategy. The guiding principles of the meta-model have been taken into account in the realization of each of the activities and participatory processes carried out.

\subsection{Limitations}

The observational and methodological limitations identified are low or unequal participation of particular sectors of the population. Not all participants lend themselves to observational study, 
interviews, meetings, etc. Divergences in the data collection of different case studies. Personal bias of observers and slow research.

\section{Results: Lessons from the Experience}

In the following section, we explore key elements to increase the likelihood of achieving the implicit objective in the rural entrepreneurship strategy as well the satisfaction of the parties involved. For that purpose, we base our results on lessons from the experiences in our case studies by considering good practices documentation [41]. According to this, a complete and justified explanation of the following points is provided:

- Identification of main actors: The identification of the main local and external actors to define a rural entrepreneurship strategy has been crucial to achieve a major involvement in the participatory processes as well as a higher acceptance of the jointly agreed elements. In addition, this identification has been a continuous process, which has allowed the inclusion of new actors and new relationships. Regarding the local population, this is justified in the existence of actors in the pilot project who no longer live in the territory but now generally live in more populated nearby municipalities or who have a close relationship with the area due to family ties. In the institutional-political sphere, the change of municipal governments in the middle of the process also involves maintaining constant communication to integrate new actors. In the business field, the relationship of these actors through training activities or new synergies also involves an updated knowledge of the business sector at a local level as well as its characteristics. This empirical experience is a process that involves covering several sub processes that change over time. With regard to identifying actors, it is very important to have up-to-date and documented information from the start that enables changes to be included and the evolution of the different relationships that are established throughout the process to be followed.

- Context and process: The context in which the experience is developed has its own characteristics that determine the objectives, tools and types of action throughout the process. The empirical experience aims to generate knowledge and a useful application for other scales and environments. To this end, a detailed explanation of the context and sub processes developed in the pilot project is provided, although the mechanisms that allow adaptability must have priority attention. Therefore, the strategy, as a process, must have a dynamic nature and a high capacity to integrate changes. For this reason, the participatory processes that include a wide range of local actors are crucial as a tool for adaptability.

- Changes or innovation results: In the context of rural unpopulated regions, the expected results in terms of changes and innovation must be considered taking into account the idiosyncrasy of these areas and the synergies that may arise from other strategies that encourage rural entrepreneurship or those derived from the application of these programs. In the case of the empirical experience, the main results take the form of projects, new entrepreneurs, synergies and, in addition, participation in an experience that has allowed all the actors involved to take part in the planning of strategies applied in their territories.

- Failures and critical success factors that have triggered the positive change being observed: main elements observed are failure to enroll all relevant actors identified due to their lack of time, interest or mistrust, among others. Despite the different activities for communication and exchange of ideas and experiences, some actors refused to participate from the beginning. Among the main success factors, we can highlight the participatory methodology, which gave a good idea of the different actors' acceptance of the strategy in real time. In addition, the continuous contact of the program managers with the entrepreneurs and other actors and the training and capacity building activities, which were positively valued by the participants.

- The risks and constraints involved in applying the practice: Among the detected risks are the possibility of abandoning the programs in the middle of the process, which has been $73 \%$ in 
the pilot project and 38\% in the scaling-up phase. It also highlights the risk of projects linked to the agricultural sector because of their dependence on the environment in which they are developed and climatic factors that, in many cases, determine their installation and continuity. As an example, two beekeepers who launched their businesses in different years with different levels of production due to climatic conditions meant that only one of them still continues with their business. In addition, many potential entrepreneurs do not have enough time to devote to the training activities because of their professional occupations and other reasons, which delays or paralyzes the launch of their projects. In the case of the scaling-up phase, the target population has been expanded by concentrating on the city of Ávila and extending these calls to the entire province. On the other hand, we do not have a baseline to compare our results and future impacts as the data on this subject is incomplete in the area.

- Impact on the community (based on appropriate evaluation and validation): The scaling-up has had an impact that has led to 83 people being trained, 30 projects being launched, in which 48 people participate as promoters, and 14 projects being funded. In addition, many of the entrepreneurs have become trainers integrated in the programs, both in the pilot project and in the scaling-up. Likewise, synergies have been generated between entrepreneurs from within and outside the area, angel investors, trainers in the academic field, etc., resulting in new collaborations. On the other hand, the impact on the scientific field from sharing this experience of rural entrepreneurship in different forums, congresses and publications, must be sought.

- Participatory approaches in order to engage stakeholders and ensure good practice ownership and sustainability: The participatory approach has been the fundamental basis of this empirical experience as described throughout the article. This approach is relevant for these kind of strategies aimed at developing rural areas in which the actors and beneficiaries involved must maintain a predominant role. Regarding the predecessors of the WWP approach mentioned in Section 3.2, we discuss five cases, which highlight the success of a participatory process: The first predecessor mentioned in Section 3.2 is a study based on a community of Aymara Women in Peru. The WWP approach is applied as a catalyst for a process of institutional structuralism to achieve social development. In this process, the success lies-among other aspects-in the willingness of the institutions and parties involved in participating and carrying out the process $[64,65]$. This aspect enriches our starting point in terms of what determines success, since it must take into account not only the parties' satisfaction but also their degree of willingness to participate. In this context, it therefore seems clear that the success of this process, to a great extent, lies in the commitment to assume approaches that encourage participation. Public institutions can play a role in assuming these approaches or, failing that, for private entities as in the two main case studies presented in this paper. The second predecessor is related to an agricultural cooperative in Murcia, Spain [66]. In this case, the WWP approach is used as a framework to deepen the concept of rural prosperity by investigating the perceptions of the members of the cooperative. This allows us to develop a definition of rural prosperity, reaching beyond the related economic aspects and integrating other contextual, social, ethical and relational aspects perceived by them. Similarly, in our case studies, these perceptions must be integrated in the same way to ensure the satisfaction of all parties. The third predecessor relates to a case study based on illicit crops in conflict areas of Colombia [67]. The WWP experience provides evidence that the process of social learning can be effective for substituting illicit crops in these areas for alternative development projects by the public and private sectors. However, it is also stressed that it does not mean that the WWP approach is always optimal in every context and it could be that multiple approaches are combined. This study doesn't point to specific aspects regarding the satisfaction of parties involved; however, it highlights the importance of the process in order to create trust and reinforce the participating governments' structures. The fourth study mentioned in Section 3.2 is focused on the role of Private Public Partnerships for sustainable rural entrepreneurship [58] in the North Highland of the Community of Madrid, Spain. It highlights that PPPs with participative structures 
are a successful way of promoting entrepreneurship and innovation in rural areas. Thus, success is related to the existence of certain participatory structures. The fifth predecessor is a study carried out in Cuenca, Spain that aims to analyse how a blueprint hydraulic engineering project is able to adapt to the needs of the territory by involving stakeholders in the project process, including the LAGs and the affected population [68]. This study concludes that "the involvement of stakeholders and local action groups in the project becomes fundamental" and also states that, "as a result of active participation from all the WWP components, the project provides new opportunities for the territory in which it is based, and is able to revitalise it". Finally, in all these cases, private entities have played a significant role.

\section{Conclusions}

The case studies presented cannot be statically representative, but they do represent relevant aspects that made the purpose of this research achievable. The case studies explore and illustrate how participatory processes could be relevant to ensure the success of rural entrepreneurship strategies in early stages of planning. Although more empirical research and temporal scope would be needed to further consolidate the related findings, they show how participatory processes enable a better understanding and acceptance of results by the local population. In turn, this leads to a more positive perception from all parts involve, which implies greater success in the terms defined in this study.

From our results, we can conclude that rural entrepreneurship can be enriched by strategies designed and assessed by the beneficiaries from the early stages of formulation.

In the absence of solutions from public initiatives to problems in certain rural areas, it is possible to achieve a new way of generating rural entrepreneurship and innovation, without relying on public institutions and funds.

The implementation of strategies has generated new ventures and capacity building through an experimental and innovative way of addressing rural development in one of the most sparsely populated rural areas of Spain. Although it contains elements of the LEADER approach-territorial approach, innovation, cooperation, building partnerships and participative structures-the model incorporates a more decentralized and independent management of public aid, by being managed and designed directly by civil society and representatives from the business sector.

Finally, it is important to note that international trends on entrepreneurship and sustainability based on enhanced responsibility, commitment and initiatives of the civil society are in line with the principles adopted in this study.

Author Contributions: A.C. conceptualized the work and designed the methodology with the support of M.L.; Both A.C. and M.L. conducted participatory processes and interviews.; M.L. carried out the data interpretation and validation, and wrote the original draft.; M.L. and M.P.P. reviewed and edited the final draft.; A.C.and M.L. were in charge of project administration.; A.C.carried out supervision, and funding and resources acquisition.

Funding: This research was funded by the Fundación Tatiana Pérez de Guzmán el Bueno.

Acknowledgments: On behalf of the authors and the Gesplan Research Group, we would like to thank the members of 'Fundación Tatiana Pérez de Guzmán el Bueno' (FTPGB) and its 'Observatorio active 1.131' for supporting and believing in initiatives such as this. The FTPGB is a non-profit foundation that manages the legacy of its founder, and has mainly social goals in youth training, scientific research and environmental fields. These aims have led the Foundation to collaborate with different Spanish universities with the objective of promoting research projects in different scientific fields. The rural environment is one of the areas where the Foundation aims to promote development initiatives and training for young people, especially women. The FTPGB's interest in this area led them to look for relevant experts and researchers within the University with experience in sustainable rural development, in order to collaborate with the Foundation in achieving its objectives. This quest materialized in 2014 through an agreement between the Foundation and the Gesplan Research Group from the 'Universidad Politécnica de Madrid' (UPM).

Conflicts of Interest: The authors declare no conflict of interest. 


\section{References}

1. Kaufmann, P.J.; Dant, R.P. Franchising and the domain of entrepreneurship research. J. Bus. Ventur. 1999, 14, 5-16. [CrossRef]

2. Van Praag, C.M.; Versloot, P.H. What is the value of entrepreneurship? A review of recent research. Small Bus. Econ. 2007, 29, 351-382.

3. Parker, S.C. The Economics of Entrepreneurship; Cambridge University Press: Cambridge, UK, 2009.

4. Shane, S.; Venkataraman, S. The promise of entrepreneurship as a field of research. Acad. Manag. Rev. 2000, 25, 217-226. [CrossRef]

5. Harms, P.D.; Credé, M. Emotional intelligence and transformational and transactional leadership: A meta-analysis. J. Leadersh. Organ. Stud. 2010, 17, 5-17. [CrossRef]

6. Schaltegger, S.; Wagner, M. Sustainable entrepreneurship and sustainability innovation: Categories and interactions. Bus. Strateg. Environ. 2011, 20, 222-237. [CrossRef]

7. Stam, E.; Spigel, B. Entrepreneurial Ecosystems and regional policy. In SAGE Handbook for Entrepreneurship and Small Business; SAGE publications: Thousand Oaks, CA, USA, 2016.

8. Naudé, W. Entrepreneurship and Economic Development: Theory, Evidence and Policy. IZA Discussion Paper No 7507. 2013. Available online: http:/ /ftp.iza.org/dp7507.pdf (accessed on 25 February 2018).

9. Gries, T.; Naudé, W. Entrepreneurship and human development: A capability approach. J. Public Econ. 2011, 95, 216-224. [CrossRef]

10. Davidsson, P. The domain of entrepreneurship research: Some suggestions. In Cognitive Approaches to Entrepreneurship Research: 265-314; Katz, J.A., Shepherd, D.A., Eds.; JAI: Amsterdam, The Netherlands, 2003.

11. Welter, F. Contextualizing entrepreneurship-Conceptual challenges and ways forward. Entrep. Theory Pract. 2011, 35, 165-184. [CrossRef]

12. Zahra, S.A.; Wright, M. Entrepreneurship's next act. Acad. Manag. Perspect. 2011, 25, 67-83. [CrossRef]

13. Watson, T.J. Entrepreneurial action and the Euro-American social science tradition: Pragmatism, realism and looking beyond 'the entrepreneur'. Entrep. Reg. Dev. 2013, 25, 16-33. [CrossRef]

14. Watson, T.J. Entrepreneurship in action: Bringing together the individual, organizational and institutional dimensions of entrepreneurial action. Entrep. Reg. Dev. 2013, 25, 404-422. [CrossRef]

15. Spedale, S.; Watson, T.J. The emergence of entrepreneurial action: At the crossroads between institutional logics and individual life-orientation. Int. Small Bus. J. 2014, 32, 759-776. [CrossRef]

16. Hopp, C.; Stephan, U. The influence of socio-cultural environments on the performance of nascent entrepreneurs: Community culture, motivation, self-efficacy and start-up success. Entrep. Reg. Dev. 2012, 24, 917-945. [CrossRef]

17. Stam, E. Entrepreneurship, evolution and geography. In The Handbook of Evolutionary Economic Geography; Boschma, R., Martin, R.L., Eds.; Edward Elgar: Cheltenham, UK, 2010; pp. 307-348.

18. Sternberg, R. Regional dimensions of entrepreneurship. Found. Trends Entrep. 2009, 5, 211-340. [CrossRef]

19. Tamásy, C. Determinants of regional entrepreneurship dynamics in contemporary Germany: A conceptual and empirical analysis. Reg. Stud. 2006, 40, 365-384. [CrossRef]

20. Spigel, B. Bourdieuian approaches to the geography of entrepreneurial cultures. Entrep. Reg. Dev. 2013, 25, 804-818. [CrossRef]

21. Müller, S.; Korsgaard, S. Resources and bridging: The role of spatial context in rural entrepreneurship. Entrep. Reg. Dev. 2018, 30, 224-255. [CrossRef]

22. North, D.; Smallbone, D. Innovative activity in SMEs and rural economic development: Some evidence from England. Eur. Plan. Stud. 2000, 8, 87-106. [CrossRef]

23. Stathopoulou, S.; Psaltopoulos, D.; Skuras, D. Rural entrepreneurship in Europe: A research framework and agenda. Ijebr 2004, 10, 404-425. [CrossRef]

24. Smallbone, D. Rural entrepreneurship. In Strengthening Entrepreneurship and Economic Development in East Germany: Lessons from Local Approaches; Hofer, J., Ed.; OECD: Paris, France, 2009; pp. 161-189.

25. Baumgartner, D.; Schulz, T.; Seidl, I. Quantifying entrepreneurship and its impact on local economic performance: A spatial assessment in rural Switzerland. Entrep. Region. Dev. 2013, 25, 222-250. [CrossRef]

26. Speech by Guy Crauser, European Commission. Director General for Regional Policy Depopulation Seminar, 12-13 June 2001, Lycksele, Sweden. Available online: https:/ / ec.europa.eu/regional_policy/archive/ sources/docconf/depop/document/crauser_en.pdf (accessed on 15 June 2018). 
27. Pato, M.L.; Teixeira, A. Twenty years of rural entrepreneurship: A bibliometric survey. Sociol. Rural. 2014, 56, 3-28. [CrossRef]

28. Meccheri, N.; Pelloni, G. Rural entrepreneurs and institutional assistance: An empirical study from mountainous Italy. Entrep. Reg. Dev. 2006, 18, 371-392. [CrossRef]

29. European Parliament Briefing, Bridging the Rural-Urban Divide Rural-Urban Partnerships in the EU. Available online: http:/ / www.europarl.europa.eu/RegData/etudes/BRIE/2016/573898/EPRS_BRI (accessed on 13 January 2018).

30. European Commission. Statistics and Indicators. Facts and Figures on EU Agriculture and the CAP: EU Rural Areas and the Primary Sector. Available online: https:/ / ec.europa.eu/agriculture/sites/agriculture/files/ statistics / facts-figures/eu-rural-areas-primary-sector.pdf (accessed on 13 January 2019).

31. European Network for Rural Development. Rural Entrepreneurship. EU Rural Review. 2011. Available online: https:/ / enrd.ec.europa.eu/sites/enrd/ files/ED5808AC-994A-47AD-928F-0D3088716910. pdf (accessed on 14 January 2019).

32. EU Funding. Available online: https:// europa.eu/european-union/about-eu/funding-grants_es (accessed on 15 June 2018).

33. Commission of the EC. Draft Notice from the Commission to Member States Laying down Guidelines for Integrated Grants for Which Member States Are Invited to Submit Proposals in the Framework of a Community Initiative for Rural Development; Commission of the EC: Brussels, Belgium, 1990.

34. European Commission. The Leader Approach: A Basic Guide; Office for Official Publications of the European Communities: Luxembourg, 2006.

35. Cazorla, A.; De los Ríos, I.; Díaz-Puente, J. The Leader community initiative as rural development model: Application in the capital region of Spain. Sci. J. Agrocienc. 2005, 39, 697-708.

36. De los Rios-Carmenado, I.; Díaz-Puente, J.M.; Cadena-Iñiguez, J. The Initiative Leader as a model for rural development: Implementation to some territories of México. Agrociencia 2011, 45, 609-624.

37. Barke, M.; Newton, M. The EU LEADER initiative and endogenous rural development: The application of the programme in two rural areas of Andalusia, southern Spain. J. Rural. Stud. 1997, 13, 319-341. [CrossRef]

38. Saraceno, E. Recent trends in rural development and their conceptualisation. J. Rural. Stud. 1994, 10, 321-330. [CrossRef]

39. Hjørland, B. The foundation of the concept of relevance. J. Am. Soc. Inf. Sci. Technol. 2010, 61, $217-237$.

40. ICB-NCB IPMA Competence Baseline, Version 3.0; International Project Management Association: Nijkerk, The Netherlands, 2009.

41. FAO. Good Practices at FAO: Experience Capitalization for Continuous Learning; Food and Agriculture Organization: Rome, Italy, 2013; Available online: http:/ / www.fao.org/3/a-ap784e.pdf (accessed on 21 June 2018).

42. Stam, E. Entrepreneurial ecosystems and regional policy: A sympathetic critique. Eur. Plan. Stud. 2015, 23, 1759-1769. [CrossRef]

43. Spigel, B. The relational organization of entrepreneurial ecosystems. Entrep. Theory Pract. 2017, 41, 49-72. [CrossRef]

44. Regulation (EC) No 1059/2003 of the European Parliament and of the Council on the Establishment of a Common Classification of Territorial Units for Statistics (NUTS). Official Journal of the European Union. 26 May 2003.

45. Rural Development Program of Castilla y León 2014-2020 v5.1. Available online: http:/ /www.jcyl.es/web/jcyl/ AgriculturaGanaderia/es/Plantilla100/1284319661743/1246464862173/_/_ (accessed on 3 March 2018).

46. Instituto Nacional de Estadística (INE). Población, Superficie y Densidad por Municipios por CCAA y Provincias. Instituto Nacional de Estadística. 2017. Available online: https: / www.ine.es/dyngs/INEbase/ es / categoria.htm?c=Estadistica_P\&cid=1254735572981 (accessed on 10 October 2018).

47. European Commission [EC]. Population density. Eurostat. 2016. Available online: https://ec.europa.eu/ eurostat/data/database (accessed on 10 October 2018).

48. Análisis y Prospectiva. Población y Sociedad Rural. (UAP Serie Agrinfo $n^{\circ} 12$ ) España; Ministerio de Medio Ambiente y Medio Rural Marino: Madrid, Spain, 2009.

49. Datos Económicos y Sociales de las Unidades Territoriales de España, 2012; Caja España-Duero: León, Spain, 2012.

50. Cruz, N.M.; Barahona, J.H.; Escudero, A.I.R.; Leitao, F.S. La formación de los emprendedores y sus consecuencias sobre la innovación y el éxito empresarial. Dir. Organ. 2010, 41, 86-95. 
51. Ministerio de Agricultura Pesca y Alimentación, MAPA. Available online: https:/ /www.mapa.gob.es/es / desarrollo-rural/temas / programas-ue/periodo-de-programacion-2000-2006/ programas-de-desarrollorural-2000-2006/programas-leader-y-proder-2/presentacion_proder.aspx (accessed on 12 January 2019).

52. Navarro, F.; Cejudo, E.; Maroto, J. Participation of disadvantaged groups and governance in the LEADER and PRODER programmes in Andalucía, Spain. Stud. Agric. Econ. 2016, 118, 47-54. [CrossRef]

53. Chinnowsky, P.; Brown, H.; Szajnman, A.; Realph, A. Developing Knowledge Landscapes through Project-Based Learning. J. Prof. Issues Eng. Educ. Pract. 2006, 132, 118-125. [CrossRef]

54. De Los Ríos, I.; Cazorla, A.; Díaz-Puente, J.M.; Yagüe, J.L. Project-based learning in engineering higher education: Two decades of teaching competences in real environments. Procedia Soc. Behav. Sci. 2010, 2, 1368-1378. [CrossRef]

55. De Los Ríos, I.; Rodríguez, F.; Pérez, C. Promoting professional Project Management skills in Engineering Higher Education: Project-based learning (PBL) strategy. Int. J. Eng. Educ. 2015, 31, 1-15.

56. Trueba, I.; Cazorla, A.; Gracia, J.J. Proyectos Empresariales: Formulación, Evaluación, 2nd ed.; Mundi Prensa: Madrid, España, 1995; ISBN 9788471145840.

57. Friedmann, J. Toward a non-Euclidian mode of planning. J. Am. Plan. Assoc. 1993, 59, 482-485. [CrossRef]

58. De Los Ríos, I.; Ortuño, M.; Rivera, M. Private-Public Partnership as a Tool to Promote Entrepreneurship for Sustainable Development: WWP Torrearte Experience. Sustainability 2016, 8, 199. [CrossRef]

59. Oddsdottir, F. Evaluations of Scaling Up; GSDRC Helpdesk Research Report 1097; GSDRC: University of Birmingham: Birmingham, UK, 2014.

60. Friedmann, J.; Planning as Social Learning. UC Berkeley: Institute of Urban and Regional Development. 1981. Available online: https:/ / escholarship.org/uc/item/0q47v754 (accessed on 3 February 2018).

61. Friedmann, J. Planning in the Public Domain: From Knowledge to Action; Princeton University Press: Princeton, NJ, USA, 1987.

62. Cazorla, A.; De los Ríos, I. Rural Development as "Working with People": A Proposal for Policy Management in Public Domain; UPM: Madrid, Spain, 2012; pp. 29-35.

63. Cazorla, A.; de los Ríos, I.; Salvo, M. Working with People (WWP) in rural development projects: A proposal from social learning. Cuad. Desarro. Rural. 2013, 10, 131-157.

64. Sastre-Merino, S.; Negrillo, X.; Hernández-Castellano, D. Sustainability of Rural Development Projects within the Working with People Model: Application to Aymara Women Communities in the Puno Region, Peru. Cuad. Desarro. Rural. 2013, 10, 219-243.

65. Cazorla, A.; Negrillo, X.; Montalvo, V.; De Nicolas, V.L. Institutional Structuralism as a Process to Achieve Social Development: Aymara Women's Community Project Based on the Working with People Model in Peru. J. Sociol. Soc. Welf. 2018, 45, 55.

66. De los Ríos, I.; Rivera, M.; García, C. Redefining rural prosperity through social learning in the cooperative sector: 25 years of experience from organic agriculture in Spain. Land Use Policy 2016, 54, 85-94. [CrossRef]

67. Ceron, C.A.A.; De los Rios-Carmenado, I.; Fernández, S.M. Illicit crops substitution and rural prosperity in armed conflict areas: A conceptual proposal based on the Working with People model in Colombia. Land Use Policy 2018, 72, 201-214. [CrossRef]

68. De Nicolás, V.L. Towards a transformational hydraulic engineering project for the territory: A focus on the Working with People (WWP) model. Land Use Policy 2016, 54, 246-252. [CrossRef]

69. De los Ríos-Carmenado, I.; Rahoveanu, A.T.; Gallegos, A.A. Project management competencies for regional development in Romania: Analysis from “Working with People" model. Procedia Econ. Financ. 2014, 8, 614-621. [CrossRef]

(C) 2019 by the authors. Licensee MDPI, Basel, Switzerland. This article is an open access article distributed under the terms and conditions of the Creative Commons Attribution (CC BY) license (http:/ / creativecommons.org/licenses/by/4.0/). 